(RESEARCH ARTICLE)

\title{
Traditional medicine in the treatment of bovine diseases in Northern Côte d'Ivoire
}

\author{
Coulibaly Kiyinlma ${ }^{1,}{ }^{*}$, Koné Kéassemon Hervé Cédessia ${ }^{1}$, Sanogo Yacouba ${ }^{1,3}$ and Zirihi Guédé Noël 2 \\ ${ }^{1}$ Department of Plant Biology, UFR of Biological Sciences, University Pelefero Gon Coulibaly, BP 1328 Korhogo, Côte \\ d'Ivoire.. \\ ${ }^{2}$ Botany research unit, U.F.R. Biosciences, University Felix Houphouet-Boigny of Cocody, 22 BP 582 Abidjan 22, Côte \\ d'Ivoire. \\ ${ }^{3}$ Laboratory of Medicinal Plants and Pharmacology. University Nangui Abrogoua of Abidjan, Côte d'Ivoire.
}

Publication history: Received on 03 May 2020; revised on 12 May 2020; accepted on 14 May 2020

Article DOI: https://doi.org/10.30574/wjarr.2020.6.2.0139

\begin{abstract}
Traditional practices involved in veterinary care are common, but are gradually disappearing because they are not being passed on to the younger generation. The present study aims to safeguard and enhance, through documentation, the knowledge as well as the ethno-medicinal veterinary practices rich in recipes, which tend to be lost or even disappear. Thus, an ethnoveterinary survey, conducted in the North of Côte d'Ivoire among 50 livestock breeders in three subprefectures of the Ferkessédougou department, reveals 34 types of recipes using 25 species of plants divided into 17 families and 21 genera. The most dominant families are the Meliaceae (23.53\%). Among the organs of all the listed plants, the leaves are the most used (32.43\%), and the majority of the remedies are obtained by decoction (56.67\%). Most of the diseases treated are diarrhoea and malaria, with a rate of 17.07\%; stomach aches, rum, foot and mouth disease and intestinal worms, each representing $7.31 \%$. The oral route is the most commonly used method of administration (93\%). The results obtained may constitute a database for further research that could reveal the efficacy of these plants.
\end{abstract}

Keywords: Medicinal plants; Côte d'Ivoire; Ethnoveterinary; Cattle; Ferkessédougou

\section{Introduction}

All over the world, as long as the history of mankind goes back, the proximity of Man to his environment has allowed him to develop a certain amount of knowledge in the field of medicine with plants. Even before the advent of chemotherapy [1], he was able to deal with the most common conditions that pose problems of morbidity and mortality. In Africa, after independence, traditional livestock farming was the only source of production and supply of poultry, cattle and sheep products.

In Côte d'Ivoire, livestock farming is still a developing economic activity, contributing about $4.5 \%$ to agricultural gross national product (PIB) and 2\% to total (PIB) [2]. Moreover, cattle breeding remains 95\% dominated by traditional practices [3]. It contributes to improving food security, diversifying and increasing the income of farmers and herders [2]. In the Ferkessédougou department, livestock farming is an important economic activity. Poor soil conditions have led the people of this northern region of Côte d'Ivoire, once described as savannah, to practice livestock rearing rather than agriculture.

In addition, the estimated $83 \%$ of the cattle population in the North is of five genetic types [4]. However, this sector of activity is experiencing enormous difficulties. Parasitic diseases [5] due to lack of care and insufficient fodder, especially in the dry season, are among the main causes of loss of animal life and low meat production. In order to ensure the health of their animals, farmers, who have a great deal of traditional knowledge, use certain plant species for veterinary

\footnotetext{
${ }^{*}$ Corresponding author: Coulibaly Kiyinlma
} 
purposes without having to resort to expensive modern pharmaceuticals. This system of care, known as veterinary ethnomedicine, has a prominent place among various pastoral peoples.

Indeed, the interest aroused by phytotherapy to overcome gastric problems and parasitic diseases, by the traditional herders of this Department, lies in the fact that the drugs used are easy to access and to prepare, moreover, their medicinal properties are recognized.

In spite of the growing interest in the research community on medicinal plants, very few indications are provided in the literature regarding traditional veterinary medicine in northern Côte d'Ivoire. Only [6], [7] and [5] are devoted to traditional practices in veterinary care. In response to this situation, a study was carried out on plants for medicinal use in cattle rearing systems in the Department of Ferkessédougou, a town located in the north of Côte d'Ivoire. The objective of this work is to safeguard and enhance through documentation, knowledge and recipient-rich ethnomedicinal veterinary practices, which tend to be gradually lost or even disappear.

\section{Material and methods}

\subsection{Study environment}

The study was carried out in Côte d'Ivoire, in the department of Ferkessédougou, located at $9^{\circ} 32$ north latitude and $6^{\circ} 29$ west longitude. The department covers an area of $3220 \mathrm{~km}^{2}$ (fig. 1) and is bordered to the south by the department of Niankaramandougou, to the east by the department of Kong, to the west by the department of Sinémantiali and to the north by the department of Ouangolodougou. It borders Mali and Burkina Faso. In the department of Ferkessédougou, 3 communes namely Ferkessédougou, Togoniere, and Koumbala have been selected. The choice of these communes is due to the fact that data from the livestock census conducted in the department showed a high concentration of cattle.

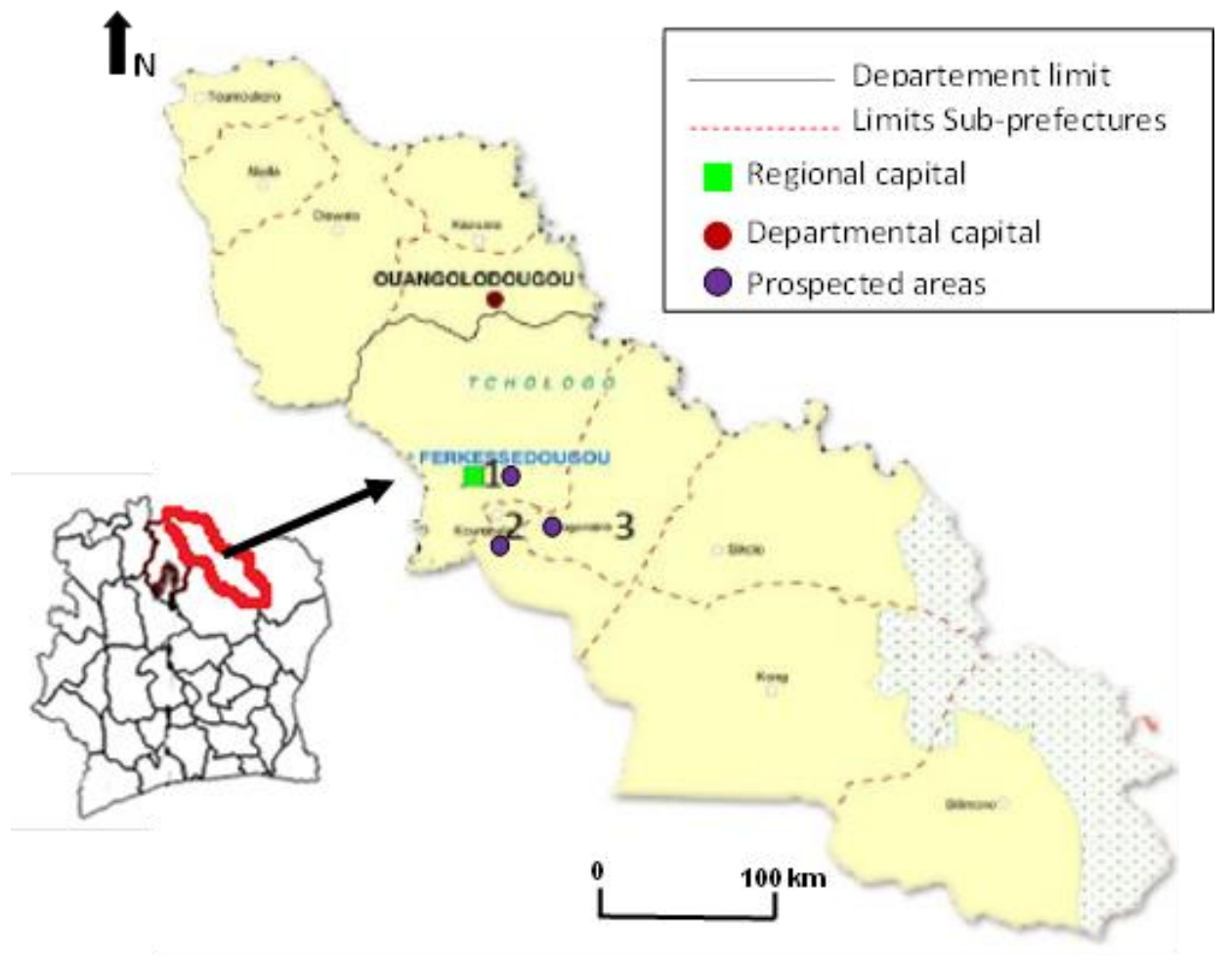

Figure 1 Map of the Ferkessédougou department

\section{$2.2 \quad$ Technical materials}

In order to have as much information as possible about the use of medicinal plants for veterinary purposes, we used survey sheets to collect information from farmers and specialized healers; a camera for taking pictures; pruning shears; plastic bags to collect plant samples; newspaper and cardboard folders for making herbariums; labels to number plant samples; a pen; a notepad for taking notes and a computer for recording and processing data. 


\section{$2.3 \quad$ Methods}

\subsubsection{Ethnobotanical survey method}

This study was preceded by a pre-investigation, during which the authorities of the Department were approached and informed of the project. Then it was the turn of the various associations of livestock farmers and healers who often treat veterinary diseases in the Department.

Surveys of veterinary plants began directly at the farm sites, during transhumance and among experienced healers, using the semi-direct interview technique, in which the respondent is asked to answer questions. A total of 50 peoples were interviewed. An interpreter was needed during the interviews, as they sometimes took place in the local language. Each interviewee was interviewed three times in order to verify the consistency of the information received. Information on a veterinary plant included information on diseases frequently contracted, the local name of the plant, the part used, the method of preparation and the method of administration or use.

\subsubsection{Botanical Nomenclature}

Herbarium samples were collected and the identification of the listed plants was made thanks to the flora of Côte $d$ 'Ivoire [8,9] and the work of [10]. The nomenclature according to [11] was used for the harmonization of the names of the listed plant species.

\subsubsection{Analysis of the data}

The various data collected were subjected to elementary descriptive statistical analyses. These analyses were carried out using Excel 2013 software.

\section{Results}

\subsection{Ethnobotanical study}

Ethnobotanical surveys conducted in the three localities of the Department of Ferkessédougou identified 25 medicinal plants and 34 recipes that are used to treat various health problems in cattle. These plants are divided into 21 genera and 17 families (Table 1). The plants are grouped into species, with families, local names, organs used, and methods of preparation and administration. From the point of view of species richness, the best represented families are Meliaceae (23.53\%), Mimosaceae, Malvaceae, Fabaceae, Sapotaceae, Annonaceae, each with 17.65\%, and Caesalpiniaceae, Caricaceae, Rubiaceae, Solanaceae with $11.76 \%$. During the survey, some plants were mentioned several times, due to the frequency of their use. These were Khaya senegalensis, Vitellaria paradoxa, Annona senegalensis, Parkia biglobosa.

\subsection{Main diseases affecting livestock in the department}

This survey identified a total of 15 veterinary pathologies, mentioned by farmers and healers. According to the respondents, the observed symptoms are classified according to their importance. Thus, diarrhoea and malaria are the most frequent diseases with a rate of $17.07 \%$ each, and for which 5 and 4 plants respectively were reported. For other diseases, farmers indicated 3 plants for stomach aches, rum, foot and mouth disease, intestinal worms, with a rate each of $7.31 \%$ and 2 plants for symptoms such as eye infections, ticks and broken horns with a respective rate of $4.88 \%$. Against infertility, cough, external and hoof wounds, with a rate of $2.44 \%$ each, only one plant was indicated (fig. 2 ).

\subsection{Parts used}

In the localities visited, remedies are frequently made from leaves (32.43\%), bark (27.52\%) and fruit (18.45\%). The other vegetable parts used represent $21.6 \%$ (fig. 3 ).

\subsection{Method of preparation and administration of remedies}

Remedies are generally made from fresh or dried plant drugs, either from a single plant or a combination of plants, which are used mainly in the form of decoctions (56.67\%), powders (20\%), juices (10\%), macerations (10\%) and grindings (3.33\%) (fig. 4). Ingredients such as lemon, vinegar, eggs, millet bran, red oil and lice are often used in some recipes. Remedies are administered orally in $93 \%$ of cases, with fumigation and poultice representing $4 \%$ and $3 \%$ respectively (fig. 5). For the herbs indicated, no side effects were reported. 
Table 1 Medicinal Plants and their Uses in Cattle Breeding Systems

\begin{tabular}{|c|c|c|c|c|c|}
\hline Species & Family & Local name & Diseases & Organs & $\begin{array}{l}\text { Preparation } \\
\text { Administration }\end{array}$ \\
\hline $\begin{array}{l}\text { Khaya senegalensis } \\
\text { (Desr.) A. Juss. . }\end{array}$ & Meliaceae & Djaraviri & Scabies & Bark & $\begin{array}{l}\text { Decoction }+ \text { Lemon juice to } \\
\text { drink }(2 \text { coffee glass once / } \\
\text { day) }\end{array}$ \\
\hline $\begin{array}{l}\text { Piliostigma thonningii } \\
\text { Schummah. Milne-Redh. }\end{array}$ & Caesalpiniaceae & Olofoo & \multirow{5}{*}{ Diarrhoea } & Leaves & $\begin{array}{l}\text { Decoction }+ \text { Lemon juice to } \\
\text { drink ( } 1 \text { coffee glass })\end{array}$ \\
\hline Sida acuta Burm.f. & Malvaceae & Tchègbènebalier & & Leaves & $\begin{array}{l}\text { Decoction to drink, } 2 \text { coffee } \\
\text { glasses }\end{array}$ \\
\hline $\begin{array}{l}\text { Detarium microcarpum } \\
\text { Guill. \& Perr }\end{array}$ & Cesalpiniaceae & Gbogbo & & Leaves & $\begin{array}{l}\text { Decoction to drink ( } 2 \text { coffee } \\
\text { glasses; } 1 \text { time / day) }\end{array}$ \\
\hline $\begin{array}{l}\text { Vitellaria paradoxa C. } \\
\text { F. Gaertn }\end{array}$ & Sapotaceae & Soun vime & & Stem & $\begin{array}{l}\text { Charcoal (drink), to drink; } \\
\text { (1 glass) }\end{array}$ \\
\hline $\begin{array}{l}\text { Feretia apodanthera } \\
\text { Delile }\end{array}$ & Rubiaceae & Commby & & Root & $\begin{array}{l}\text { Macerate }+ \text { millet flour to } \\
\text { drink ( } 2 \text { glasses of tea) }\end{array}$ \\
\hline Gossypium sp. & Malvaceae & Lomouroutantigué & \multirow{2}{*}{$\begin{array}{l}\text { Constipatio } \\
\mathrm{n}\end{array}$} & Fruit & $\begin{array}{l}\text { Juice }+ \text { vinegar to drink ( } 2 \\
\text { glasses of tea) }\end{array}$ \\
\hline Elaeis guineensis Jacq. & Arecaceae & Téntigue & & Fruit & $\begin{array}{l}\text { Red drinking oil (1 coffee } \\
\text { glass) }\end{array}$ \\
\hline Carica papaya. L. & Caricaceae & Mahandié & \multirow{3}{*}{$\begin{array}{l}\text { Stomach } \\
\text { aches }\end{array}$} & Bark & $\begin{array}{l}\text { Décoction à boire (1 verre / } \\
\text { Jour) }\end{array}$ \\
\hline $\begin{array}{ll}\text { Parkia } & \text { biglobosa } \\
\text { (Jacq.) R. Br } & \end{array}$ & Mimosaceae & Néré & & Bark & $\begin{array}{l}\text { Decoction to drink (1 glass / } \\
\text { Day) }\end{array}$ \\
\hline $\begin{array}{l}\text { Annona senegalensis } \\
\text { Pers. }\end{array}$ & Annonaceae & $\begin{array}{l}\text { Sousoungb- } \\
\text { gbeni }\end{array}$ & & Stem & $\begin{array}{l}\text { Decoction to drink, } 1 \text { glass } 2 \\
\text { times / Day }\end{array}$ \\
\hline Gossypium sp. & Malvaceae & Lomouroutantigué & \multirow{3}{*}{ Cold } & Fruit & Put the juice in the nostrils \\
\hline Allium cepa $\mathrm{L}$. & Liliaceae & Djabalo & & Bulb & Put the juice in the nostrils \\
\hline $\begin{array}{l}\text { Cassia occidentalis (L.) } \\
\text { Link }\end{array}$ & Fabaceae & Kinkeliba tcheman & & Leaves & $\begin{array}{l}\text { Decoction to be drunk; } 2 \\
\text { coffee glasses / Day }\end{array}$ \\
\hline $\begin{array}{l}\text { Annona senegalensis } \\
\text { pers }\end{array}$ & Annonaceae & $\begin{array}{l}\text { Sousoungb- } \\
\text { gbeni }\end{array}$ & \multirow{2}{*}{$\begin{array}{l}\text { Eye } \\
\text { infections }\end{array}$} & Bark & $\begin{array}{l}\text { Macerate and put drops on } \\
\text { the eyes }\end{array}$ \\
\hline $\begin{array}{l}\text { Cola acuminate ( } \underline{\mathrm{P}} . \\
\text { Beauv. }) \text { Schott \& Endl. }\end{array}$ & Sterculiaceae & Worotigue & & Fruit & $\begin{array}{l}\text { Apply the powder to the } \\
\text { eyes }\end{array}$ \\
\hline Nicotiana tabacum L. & Solanaceae & Tahaba & \multirow{3}{*}{$\begin{array}{l}\text { Foot-and- } \\
\text { mouth } \\
\text { disease }\end{array}$} & Leaves & $\begin{array}{l}\text { Drinking decoction ( } 2 \text { coffee } \\
\text { glasses / day) }\end{array}$ \\
\hline Parkia biglobosa $\mathrm{R} . \mathrm{Br}$ & Mimosaceae & Néré & & Fruit & $\begin{array}{l}\text { Give the powder to the } \\
\text { animal }\end{array}$ \\
\hline Nicotiana tabacum L. & Solanaceae & Tahaba & & Leaves & Fumigation (evenings) \\
\hline $\begin{array}{l}\text { Vitellaria paradoxa C.F. } \\
\text { Gaertn }\end{array}$ & Sapotaceae & Soun vime & Sterility & $\begin{array}{l}\text { Stem } \\
\text { marrow }\end{array}$ & $\begin{array}{l}\text { Macerate + Fresh egg }+1 \text { lice } \\
\text { (to drink) }\end{array}$ \\
\hline $\begin{array}{l}\text { Khaya senegalensis } \\
\text { (Desr.) A. Juss. }\end{array}$ & Meliaceae & Djaraviri & \multirow{4}{*}{ Malaria } & Bark & $\begin{array}{l}\text { Drinking decoction }(1 / 2 \\
\text { liter / Days })\end{array}$ \\
\hline $\begin{array}{l}\text { Annona senegalensis } \\
\text { Pers. }\end{array}$ & Annonaceae & $\begin{array}{l}\text { Sousoungb- } \\
\text { gbeni }\end{array}$ & & $\begin{array}{l}\text { Root- } \\
\text { leaves }\end{array}$ & $\begin{array}{l}\text { Drinking decoction (1 glass, } \\
3 \text { times / day) }\end{array}$ \\
\hline Cassia hirsuta L. & Fabaceae & $\begin{array}{l}\text { Kinkeliba } \\
\text { moussoman }\end{array}$ & & Leaves & $\begin{array}{l}\text { Drinking decoction }(1 / 2 \\
\text { liter / Days) }\end{array}$ \\
\hline $\begin{array}{l}\text { Vitellaria paradoxa C. } \\
\text { F. Gaertn. }\end{array}$ & Sapotaceae & Soun vime & & Bark & $\begin{array}{l}\text { Drinking decoction }(1 / 2 \\
\text { liter, } 2 \text { times / day) }\end{array}$ \\
\hline
\end{tabular}




\begin{tabular}{|c|c|c|c|c|c|}
\hline $\begin{array}{l}\text { Phyllanthus } \\
\text { pentandrus Schumach. } \\
\text { \& Thonn. }\end{array}$ & Phyllanthaceae & Barboube & \multirow{2}{*}{$\begin{array}{l}\text { Horn } \\
\text { breakage }\end{array}$} & Leaves & $\begin{array}{l}\text { Apply the powder on the } \\
\text { break }\end{array}$ \\
\hline $\begin{array}{l}\text { Mitragyna inermis } \\
\text { Willd. }\end{array}$ & Rubiaceae & Koylie ou liyirimin & & Leaves & $\begin{array}{l}\text { Apply the powder on the } \\
\text { break }\end{array}$ \\
\hline Carica papaya. L. & Caricaceae & Magandjé & \multirow{3}{*}{$\begin{array}{l}\text { Intestinal } \\
\text { worms }\end{array}$} & $\begin{array}{l}\text { Seed } \\
\text { (seeds) }\end{array}$ & $\begin{array}{l}\text { Broyat (drink) to drink, one } \\
\text { glass / Day }\end{array}$ \\
\hline $\begin{array}{l}\text { Khaya senegalensis } \\
\text { (Desr.) A. Juss. }\end{array}$ & Meliaceae & Djaraviri & & Bark & $\begin{array}{l}\text { Powder + crushed corn (to } \\
\text { eat) }\end{array}$ \\
\hline Cassia siamea Lam. & Fabaceae & Cassia & & Leaves & $\begin{array}{l}\text { Drinking decoction, } 1 \text { glass } 2 \\
\text { times / day }\end{array}$ \\
\hline $\begin{array}{l}\text { Anogeissus leiocarpus } \\
\text { Guill. \& Perr. }\end{array}$ & Combretaceae & Guenmin & Cough & $\begin{array}{l}\text { Trunk- } \\
\text { bark }\end{array}$ & $\begin{array}{l}\text { Drinking decoction } \\
\text { liter; } 3 \text { times / day) }\end{array}$ \\
\hline $\begin{array}{l}\text { Ficus vallis-choudae } \\
\text { Delile. }\end{array}$ & Moraceae & Yibbé & \multirow{2}{*}{ Ticks } & $\begin{array}{l}\text { Trunk- } \\
\text { bark }\end{array}$ & $\begin{array}{l}\text { Drinking decoction } 1 / 2 \text { liter, } \\
2 \text { times / day }\end{array}$ \\
\hline $\begin{array}{l}\text { Anthostema } \\
\text { senegalense A. Juss }\end{array}$ & Euphorbiaceae & Lakonemon & & Leaves & $\begin{array}{l}\text { Drinking decoction (1 coffee } \\
\text { glass / day) }\end{array}$ \\
\hline Parkia biglobosa R. Br & Mimosaceae & Néré & $\begin{array}{l}\text { Hoof } \\
\text { wound }\end{array}$ & Fruit & $\begin{array}{l}\text { Applying the powder to the } \\
\text { wound }\end{array}$ \\
\hline $\begin{array}{l}\text { Khaya senegalensis } \\
\text { (Desr.) A. Juss. }\end{array}$ & Meliaceae & Djaraviri & $\begin{array}{l}\text { External } \\
\text { wound }\end{array}$ & Bark & Poultice \\
\hline
\end{tabular}

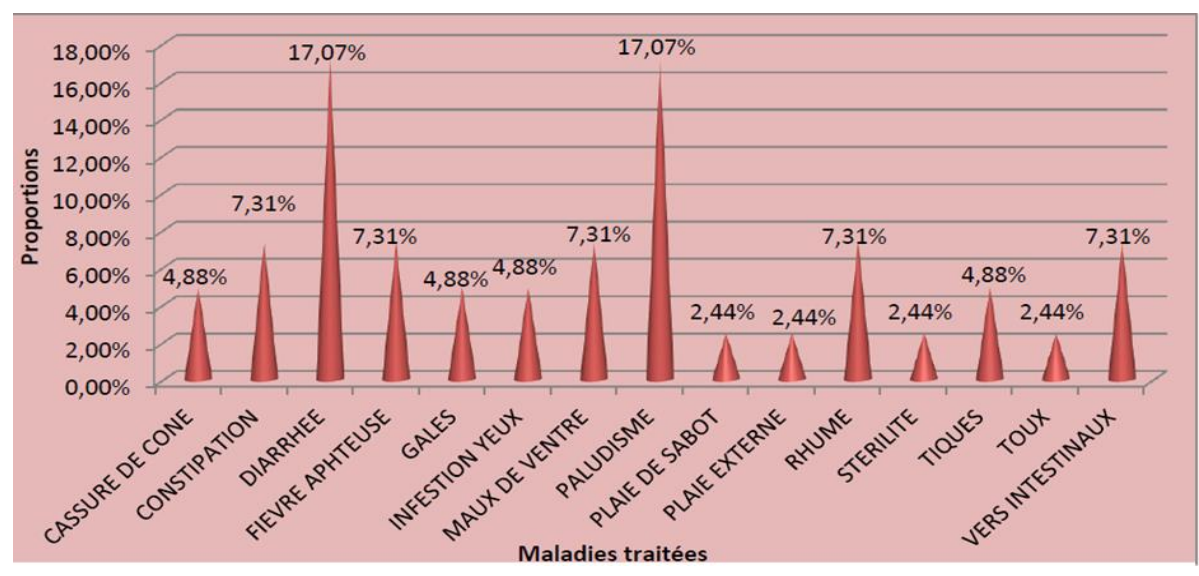

Figure 2 Different diseases treated by plants in cattle breeding

English name of the various diseases which are cited in French in Figure 2

\begin{tabular}{llll}
\hline French & English & French & English \\
\hline Cassure de corne & Horn break & Plaie de sabot & Hoof wound \\
Constipation & Constipation & Plaie externe & External wound \\
Diarrhée & diarrhoea & Rhume & Cold \\
Fièvre aphteuse & Foot-and-mouth disease & Stérilité & Sterility \\
Gales & Scabies & Tiques & Ticks \\
Infection yeux & Eye infection & Toux & Cough \\
Maux de ventre & Stomach aches & Vers intestinaux & Intestinal worms \\
Paludisme & Malaria & & \\
\hline
\end{tabular}




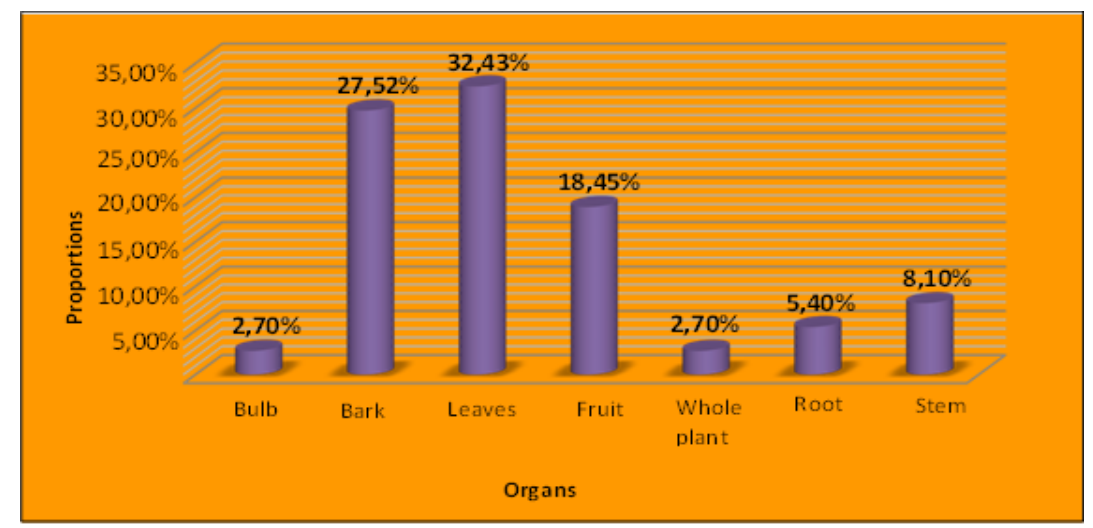

Figure 3 Proportion of plant organs used for processing cattle

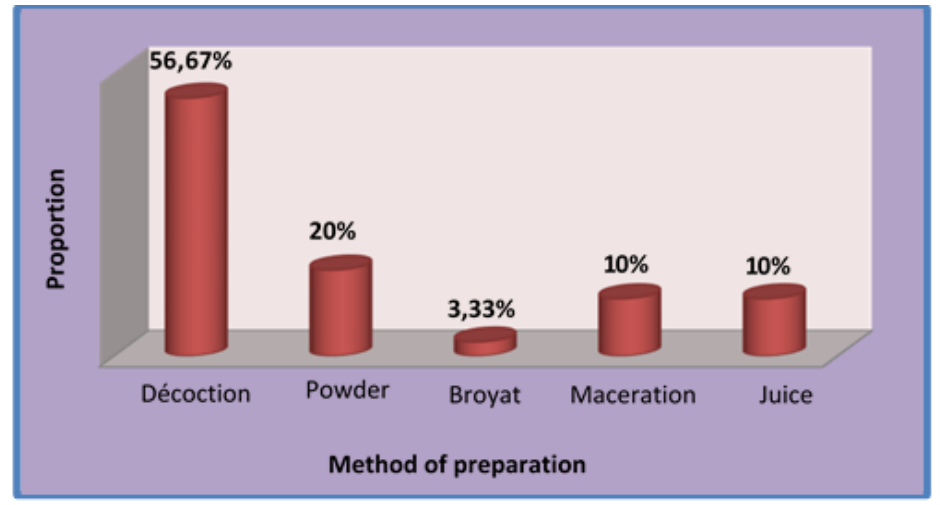

Figure 4 Proportion of different methods of making remedies for cattle.

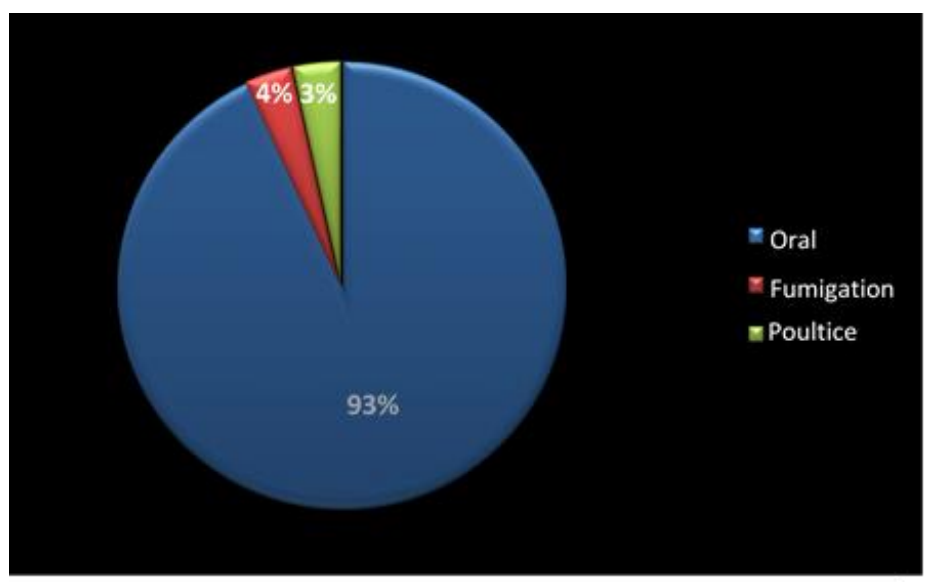

Figure 5 Proportion of different methods of administering remedies in cattle.

\section{Discussion}

Ethno-veterinary surveys on the treatment of bovine diseases in the Ferkessédougou zone have identified 25 medicinal plants that are used in the preparation of 34 drug recipes, which are used in the prevention and treatment of 15 diseases, with a view to improving animal production. However, the low quantity of plants inventoried could be explained by the fact that the Ferkessédougou department has undergone modernization in recent decades, leading herders to abandon much of their traditional veterinary practice in favour of conventional veterinary medicine. It could also be explained by the abusive and uncontrolled exploitation of the plant resources of this region, which has led to the disappearance of several medicinal plants. In addition, the survey revealed that the herders, who are mostly Fulani, have a great deal 
of knowledge and mastery of medicinal plants, but they are not very open, especially when it comes to passing on the knowledge they possess. Moreover, these herders and healers remain more attached to traditional human rather than veterinary medicine. These results confirm the work of [7], carried out in the same Department. However, the use of medicinal plants by herders has not completely disappeared. They are used by them to administer first aid to animals. Thus, for the treatment of the most widespread diseases or symptoms, various ethno-veterinary recipes based on plants have been identified. The species Vitellaria paradoxa has been cited by farmers in cases of diarrhoea and malaria. Khaya senegalensis is involved in the therapeutic indication of intestinal worms and malaria. This confirms the observations made by [12] which indicate the confirmed use of these plants in the treatment of these bovine diseases. It is also noted that some of the same plants can be used to treat several pathologies. This is the case, apart from Vitellaria paradoxa and Khaya senegalensis, of Carica papaya for intestinal worms and bellyache. Annona senegalensis is indicated for stomach aches, eye infections and malaria. Among the plant species listed, some are also used to treat other identified pathologies. For example, there are species such as Nicotiana tabacum and Parkia biglobosa used in the treatment of foot and mouth disease, Annona senegalensis and Cola acuminata used for eye problems or Ficus vallis-choudae and Anthostema senegalense to treat ticks. For the preparation of the remedies, the breeders and healers harvest the parts of the plant that are used in the preparation of the recipe. The leaves are the most commonly used organs in the various medicinal preparations with a proportion of 32.43\%, as shown in [13] and [4]. This high use of leaves can be explained on the one hand by their abundance and on the other hand by their availability and relatively easy handling [14]. Drug recipes are generally obtained by decoction (53.65\%). The decoction, which is an empirical practice, is made at a high temperature from cold water. According to [7], it has the advantage of neutralizing pathogens and making the preparation healthy. However, the rise in temperature could lead to the loss of substances of interest from the plant that could reduce the biological activity of the drug. Moreover, the set of products obtained from the drugs from the plants listed, that is., the powder, the grind, the maceration and the juice, depends on the type of pathology to be treated. Often for the preparation of certain remedies, farmers and healers add certain ingredients to the drugs, such as vinegar, fresh eggs, millet flour, corn flour and lemon. The purpose of making this composition is to make it pleasant to ingest the drugs, which sometimes have a bitter taste [12]. This preparation process clearly shows the mastery of the effectiveness of the methods used by these herders and pastoralists in the treatment of livestock diseases. The method of administration mainly used is the oral route with a percentage of 93\% [15]. This result also reflects that of [16], who in his work on plants indicated as anti-anthelmintic, revealed that the oral route is the most appropriate in traditional phytotherapy. However, other methods such as fumigation, cataplasm and local applications are also used. Among the 25 plants obtained during this study, 7 species were identified by the studies of [12]. Among these 7 species, only 2 corroborate our study, because of their use to control diarrhoea (Vitellaria paradoxa) and intestinal worms (Khaya senegalensis and Vitellaria paradoxa) in cattle. The other 5 have prescriptions contrary to those obtained in this study.

\section{Conclusion}

This study showed that, out of the inventory of current knowledge on veterinary medicinal plants in the department of Ferkessédougou, 25 plants are used in cattle health care, with the family Meliaceae having more species. A total of 15 veterinary pathologies were mentioned by herders and healers, of which diarrhoea and malaria are the most common. This study has led to the understanding that leaves and then bark and fruit are the most commonly used parts in the preparation of remedies. In addition, it showed that decoction is the method of preparation and the oral route is the method of administration of herbal products. This observation justifies both the need and the urgency of conducting large-scale ethno-veterinary studies to safeguard what remains of local knowledge which is in danger of disappearing for good.

\section{Compliance with ethical standards}

\section{Acknowledgments}

The authors would like to thank the Direction des Eaux et Forêts and SODEFOR for their material and technical support. They also express their gratitude to the herders and healers who contributed to this study.

\section{Disclosure of conflict of interest}

The authors declare no conflict of interest.

\section{Author's contributions}

CK: validation of the research protocol, execution of the work, writing and correction of the manuscript; KKHC: execution of the work, identification of the plants, correction of the manuscript; SY: support to the bibliographical 
research, data collection and correction of the manuscript; ZGN support to the elaboration of the whole document by closely supervising all the work contributing to the manuscript.

\section{Statement of informed consent}

Each actor interviewed gave their consent deliberately and was willing to answer the different questions.

\section{References}

[1] Noman A. (2003). Influence of different doses of nitrogen fertilizer on ajwain. M.Sc. Dissertation.pp-1. Univ. of Agric. Faisalabad. Pakistan, 751-759.

[2] Anonymous A. (2013). Ministère des Ressources Animales et Halieutiques. Politique de développement de l'élevage en Côte d'Ivoire, 9th Conference of African Ministers in charge of Animal Resources. Direction de la Planification et des Programmes (DPP), 13.

[3] Anonymous B. (2014). Ministry of Animal Resources and Fisheries. Plan stratégique de développement de l'élevage, de la pêche et de l'aquaculture en Côte d'Ivoire (PSDEPA 2014-2020). Tome I, Diagnosis -Development strategy - Orientations.

[4] Koffi-Koumi M, Mamadou TT and Bakar BM. (2001). L'élevage en Côte d'Ivoire; poids économique, développement et enjeu du secteur, Côte d'Ivoire, 16.

[5] Koné KHC, Coulibaly K and Konan KS. (2019). Identification of some plants used in ethnovinarian medicine in Sinématiali (North of Ivory Coast). Jounal of Applied Biosciences, 135, 13766- 13774.

[6] Aké-Assi L and Guinko S. (1991). Plantes utilisées dans la médecine traditionnelle en Afrique de l'Ouest, Edition Roche, Basel, Switzerland, 151.

[7] Koné MW. (2005). Potential of medicinal plants from Côte d'Ivoire in the control of haemonchoses in sheep. Doctoral thesis from the University of Cocody, UFR Biosciences, Laboratoire de Botanique, 202.

[8] Aké-Assi L. (2001). Flore de la Côte d'Ivoire: catalogue Systématique, Biogéographique et Écologique. Boissiera, Conservatoire et Jardin botanique de Genève, 396.

[9] Aké-Assi L. (2002). Flore de la Côte d'Ivoire; catalogue Systématique, Biogéographique et Écologique. Boissiera, Conservatoire et Jardin botanique de Genève, 401.

[10] Arbonnier M. (2000). Trees, shrubs and lianas in dry areas of West Africa, CIRAD, Montpellier (France), 541.

[11] APG III. (2009). The Angiosperm Phylogeny Group, « An update of the Angiosperm Phylogeny Group classification for the orders and families of flowering plants: APG III », Botanical Jounal of the Linnean. Soc., 161(2), 105-121.

[12] Koné WM and Atindehou Kamanzi K. (2008). Ethnobotanical inventory of medicinal plants used in traditional veterinarymedicine in Northern Côte d'Ivoire (West Africa). South African. Journal of Botany, 74, 76-84.

[13] Dassou HG, Ogni CA, Yédomonhan H, Adomou AC, Tossou M, Dougnon JT and Akoègninou A. (2014). Diversity, veterinary uses and vulnerability of medicinal plants in North Benin. International Journal of Biological and Chemical Sciences, 8(1), 189-210.

[14] Tra Bi FH. (2008). Evaluation of the antifungal activity of fifteen (15) plants of the flora of the Ivory Coast. PhD thesis, University of Abobo-Adjamé, Abidjan, Côte d'Ivoire, 122.

[15] Merazi Yahya, Hammadi Kheira and Fedoul Firdaous Faiza. (2016). Ethno-Veterinary Approach to Medicinal Plants Used in the Region of Sidi Bel Abbes- Algeria. European Scientific Journal, 12(18), 1857 - 7881.

[16] Betti JL. (2000). Plants indicated as anthelmintics in traditional therapy in the Dja Biosphere Reserve (Cameroon). Soma, I, 4-16.

\section{How to cite this article}

Coulibaly K, Koné Kéassemon HC, Sanogo Y and Zirihi GN. (2020). Traditional medicine in the treatment of bovine diseases in Northern Côte d'Ivoire. World Journal of Advanced Research and Reviews, 6(2), 103-110. 